\title{
THE EFFECT OF PRENATAL GENTLE YOGA AND HYPNOTHERAPY ON ANXIETY LEVEL AND SLEEP QUALITY IN THE THIRD TRIMESTER PREGNANT WOMAN AT PUSKESMAS SUMBER CIREBON REGENCY IN 2019
}

\author{
Nurlaela Kurnia Rahayu, Pepi Hapitria, Rani Widiyanti \\ Poltekkes Kemenkes Tasikmalaya \\ nkduabelasrahayu@gmail.com
}

\begin{abstract}
As the pregnancy gets older, the attention and thoughts of pregnant women begin to focus on something that is considered as a climax, so that the anxiety experienced will intensify just before the childbirth. Excessive anxiety and sleep disorders during pregnancy can cause mental disorders in pregnant women and inhibit fetal growth. To determine the effect of prenatal gentle yoga and hypnotherapy on anxiety level and sleep quality in the third trimester pregnant women. This is a quasi-experimental study with a pre-post test with a control group. The sample was 32 respondents consisting of 16 respondents as an intervention group and 16 respondents as a control group taken by purposive sampling. The analysis used was the Paired T-test. There is a difference in the average of anxiety level in the third trimester pregnant women in the intervention and control groups with a $\mathrm{p}$ value 0,000 ; there is a difference in the average of sleep quality in the third trimester pregnant women in the intervention and control groups with a p value 0,000; and there is no difference in the average of anxiety level and sleep quality in the third trimester pregnant women in the intervention and control groups with a p value 0,64 . Prenatal Gentle Yoga and Hypnotherapy have an effect in reducing the anxiety level and improving the sleep quality in the third trimester pregnant women.
\end{abstract}

Keywords: Anxiety ; Hypnotherapy ; Prenatal Gentle Yoga ; Sleep Quality

\section{Introduction}

WHO estimates that every day around the world around 830 women die from pregnancy and childbirth and 99\% of maternal deaths occur in developing countries. (WHO, 2016). In Indonesia, 
MMR has decreased from 359 per 100,000 live births that occurred in 2012 to 305 per 100,000 live births in 2015. Although there has been a decrease, MMR in Indonesia has not yet reached the Long-Term Development target in the Health Sector 2005-2025, which can be reduced to 74 per 100,000 live births (Kemenkes, 2015)

The causes of maternal death due to pregnancy or childbirth are due to medical, social, cultural and religious aspects. One such medical aspect is labor with complications. One of the causes of complications in pregnancy is stress. In Indonesia, there are $107,000 \quad(28.7 \%)$ pregnant women who experience anxiety in facing childbirth (Rahmitha, 2017).

The anxiety levels was indirectly one of problems associated with high rate of maternal mortality and maternal morbidity. Anxiety often interferes with sleep. A decrease in sleep quality in pregnant women can cause a decrease in the condition of pregnant women, reduced concentration, fatigue, body aches, not in mood to work, and tend to be emotional. This can make burden of pregnancy even heavier (Nurcahya, 2017).

There are many nonpharmacological methods developed by many health practitioners in dealing with problems of pregnant women, including doing pregnancy exercise, yoga, relaxation, hypnobirthing and so on (Sindhu, 2011).

According to research results from (Pongsibidang, GS, 2019) and (Safriani, 2017), prenatal gentle yoga plays an important role in reducing anxiety level of pregnant women and improving sleep quality when entering third trimester of pregnancy.

Another method that can be done is hypnotherapy in pregnancy. Through hypnotherapy exercises, a pregnant woman is able to enter a state of deep relaxation so that she can maintain her calm and emotional stability. Emotional conditions are calm, comfortable, stable and diligent in instilling positive affirmations. Relaxation as a technique that has been proven to reduce anxiety in various subjects has also been shown to be effective in reducing anxiety in pregnant women (Kuswandi, 2014)

Based on the results of a preliminary study in form of interviews with 9 pregnant women third trimester carried out at Sumber Public Health Center, it was found that 7 out of 9 pregnant women interviewed experienced sleep disorders during pregnancy. They complained of anxiety and fear when 
entering third trimester about how the baby will be born.

\section{Method}

The research design used a quasy experiment research design. The research design used in this study was Pre and Post Test with Control Group, which is an experimental study using a comparison group (control), previously 2 groups had pre-test observations, so that the researcher could compare changes after doing experiment proven by post test (Notoatmodjo, 2012).

The population in this study were all pregnant women in work area of Sumber Public Health Center from August to November 2019 with as many as 47 people. Of the 47 pregnant women, 32 were pregnant according to inclusion criteria. This sample was divided into 2 groups, that are 16 respondents in intervention group and 16 respondents in control group.

The intervention group was given prenatal gentle yoga 2 times a week for 2 weeks with a duration of 2 hours each meeting and was guided by researcher. The control group was given hypnotherapy by researchers, respondents were taught to be able to do self-hypno at home for 7 days in 10-20 minutes before sleep at night and given hypnotherapy observation sheets. The researcher had a certificate in prenatal gentle yoga and hypnotherapy.

This study used a parametric test, that are paired t-test to determine effect of prenatal gentle yoga and hypnotherapy on anxiety levels and sleep quality before and after intervention.

\section{Results}

Based on data collected and analyzed, the following results were obtained:

Analysis of Differences in Anxiety Levels in Prenatal Gentle Yoga and Hypnotherapy Groups

Table 1 shows the results of paired T-test for prenatal gentle yoga and hypnotherapy groups, $\mathrm{p}$ value for anxiety levels was $0.00(\mathrm{p}<0.05)$ with a mean difference of 14.56 and 8,06. Statistically, there were significant difference in the mean anxiety levels in pre and post test scores in prenatal gentle yoga and hypnotherapy groups.

Analysis of Differences in Sleep Quality in Prenatal Gentle Yoga and Hypnotherapy Groups 
Table 2 shows the results of paired T-test for prenatal gentle yoga and hypnotherapy groups, $\mathrm{p}$ value for sleep quality was $0.00(\mathrm{p}<0.05)$ with a mean difference of 5,06 and 4,69. Statistically, there were significant difference at mean sleep quality in pre and post test scores in prenatal gentle yoga and hypnotherapy groups.

Table 1. Paired T-test Anxiety Levels Pregnant Women Third Trimester In Prenatal Gentle Yoga Dan Hypnotherapy Group

\begin{tabular}{|c|c|c|c|c|c|}
\hline Groups & Variable & Mean & $\begin{array}{c}\text { Mean } \\
\text { Difference }\end{array}$ & SD & $p$ value \\
\hline \multirow{2}{*}{$\begin{array}{c}\text { Prenatal gentle } \\
\text { yoga }\end{array}$} & Pre Test & 48,81 & \multirow{2}{*}{14,56} & \multirow{2}{*}{11,79} & \multirow{2}{*}{0,00} \\
\hline & Post Test & 34,25 & & & \\
\hline \multirow{2}{*}{ Hypnotherapy } & Pre Test & 44,25 & \multirow{2}{*}{8,06} & \multirow{2}{*}{6,64} & \multirow{2}{*}{0,00} \\
\hline & Post Test & 36,19 & & & \\
\hline
\end{tabular}

Table 2. Paired T-test Sleep Quality Pregnant Women Third Trimester In Prenatal Gentle Yoga Dan Hypnotherapy Group

\begin{tabular}{|c|c|c|c|c|c|}
\hline Groups & Variable & Mean & $\begin{array}{c}\text { Mean } \\
\text { Difference }\end{array}$ & SD & $p$ value \\
\hline \multirow{2}{*}{$\begin{array}{c}\text { Prenatal gentle } \\
\text { yoga }\end{array}$} & Pre Test & 9,94 & \multirow{2}{*}{5,06} & \multirow{2}{*}{2,02} & \multirow{2}{*}{0,00} \\
\hline & Post Test & 4,88 & & & \\
\hline \multirow{2}{*}{ Hypnotherapy } & Pre Test & 9,94 & \multirow{2}{*}{4,69} & \multirow{2}{*}{1,85} & \multirow{2}{*}{0,00} \\
\hline & Post Test & 5,25 & & & \\
\hline
\end{tabular}

Table 3. Independent T-test Anxiety Levels and Sleep Quality Pregnant Women Third Trimester In Prenatal Gentle Yoga Dan Hypnotherapy Group

\begin{tabular}{lccc}
\multicolumn{1}{c}{ Variable } & Mean & p value & $\begin{array}{c}\text { Mean Difference } \\
(\mathbf{C I} \text { 95\%) }\end{array}$ \\
\hline $\begin{array}{l}\text { Anxiety Levels } \\
\text { - Prenatal gentle yoga } \\
\text { - Hypnotherapy }\end{array}$ & 34,25 & & \\
\cline { 2 - 2 } $\begin{array}{l}\text { Sleep Quality } \\
\text { - Prenatal gentle yoga }\end{array}$ & 36,50 & 0,40 & $-2,25(-7,65-3,15)$ \\
\hline
\end{tabular}




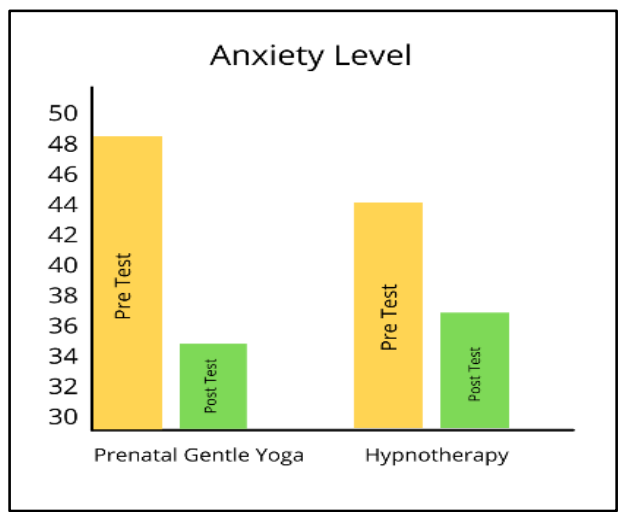

Figure 1. Anxiety Levels

\section{Discussion}

Anxiety level in Pregnant Women

The results of analysis are in Table 1 with pre-test score of anxiety level in prenatal gentle yoga group of 48.51 and post-test score of 34.25. In the hypnotherapy group, pre-test score was 44.25 and post-test score was 36.19.

This shows that the level of anxiety before and after the intervention there is a decrease in anxiety level, as evidenced by the lower the average value of before and after intervention in both groups. Whereas previously respondents had never followed and felt the benefits of prenatal gentle yoga and hypnotherapy.

Pregnant women experience anxiety caused by increase in the hormone progesterone. In addition to making pregnant women feel anxious,

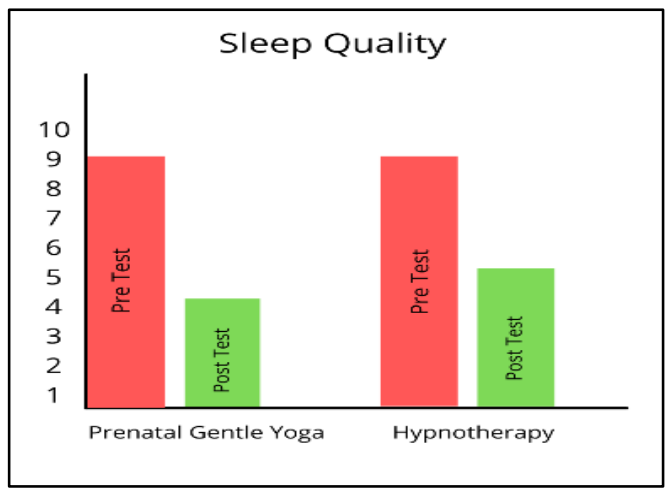

Figure 2. Sleep Qulity

this increase in hormones also causes emotional disturbances and makes pregnant women tired quickly. Another hormone that increases during pregnancy is hormone adrenaline. Hormone adrenaline can cause a dysregulation of the body's biochemistry, causing physical stress to appear in pregnant women such as irritability, anxiety, inability to concentrate, doubt, maybe even want to escape the realities of life (Priharyanti, W, 2018)

These results are in line with research conducted by (Gusti, N,. dan Paramitha, A, 2017), Analysis of effect of antenatal yoga on anxiety levels in Q III pregnant women in facing the labor process in the study, the $\mathrm{p}$ value was 0.00 smaller than $\alpha 0.05$, then $\mathrm{H} 0$ rejected or hypothesis in this study was accepted, namely that there was an effect of giving antenatal yoga 
on the level of anxiety in TW III pregnant women in facing the labor process.

Sleep quality in Pregnant Women

Table 2, the results of pre-test analysis of sleep quality in prenatal gentle yoga group of 9.94 and post-test value of 4.88. In hypnotherapy group, pre-test score was 9.94 and post-test score was 5.25. This shows that quality of sleep before and after intervention there is a decrease in average quality of sleep.

This research is in line with results of research conducted by (Safriani, 2017), there was an increase in the results of measuring sleep quality before and after doing yoga exercises and by paying attention to the results of Wilcoxon statistical test which showed a significance value of $p(0.00)$ which means $p<0.05$ or $\mathrm{H} 1$ accepted, which means that there is an effect of yoga exercises on sleep quality of third trimester pregnant women in Plandaan Jombang Public Health Center Work Area.

Prenatal yoga practice has a larger portion of physical exercise than relaxing portion. By relaxing and stretching muscles a person can relieve muscle contraction and experience a relaxed state in the body. It turns out that, physical exercise helps pregnant women reduce their physical complaints, such as back pain, bleg cramps, and improving sleep quality (Fauziah L . et al, 2016).

Whereas in hypnotherapy, it can affect a person's relaxation due to secretion of hormone melatonin which is influenced by decrease in a person's brain waves down in delta waves. When in delta waves, brain will produce human growth hormone, which is serotonin, which is good for health. When a person reaches delta waves, the pineal gland will change substance serotonin into melatonin which is important to affect sleep quality, so that they feel good while sleeping and regulate the circadian rhythm. (Hidayat, S., dan Mumpuningtias, 2018)

\section{Conclusion}

Prenatal Gentle Yoga and hypnotherapy have an effect in reducing anxiety levels and improving sleep quality in third trimester pregnant women

\section{Suggestion}

Pregnant women are expected to be able to exercise regularly like prenatal gentle yoga and hypnotherapy, to reduce complaints during pregnancy such as anxiety and improve sleep quality.

\section{Reference}




\section{DOI: 10.34305/gemic.v1i1.311}

Fauziah L . et al. (2016). Efektivitas

Latihan Yoga Prenatal Dalam

Menurunkan Kecemasan Pada Ibu

Primigravida Trimester III.

Padjajaran.

Gusti, N,. dan Paramitha, A. (2017).

Pengaruh Yoga Antenatal Terhadap

Tingkat Kecemasan Pada Ibu Hamil

Trimester III Dalam Menghadapi

Proses Persalinan Di Klinik Yayasan

Bumi Sehat. Kesehatan Terpadu 1(1) :

1-5 Issn : 2549 - 8479, 1(1), 1-5.

Hidayat, S., dan Mumpuningtias. (2018).

Terapi Kombinasi Sugesti Dan Dzikir

Dalam Peningkatan Kualitas Tidur

Pasien Syaifurrahman. Ilmiah Ilmu

Kesehatan, 6(3), 219-230.

Kemenkes, R. (2015). Profil Kesehatan

Indonesia.

Kuswandi, L. (2014). Keajaiban Hypnobirthing. Pustaka Bunda.

Notoatmodjo, S. (2012). Metodologi Penelitian.

Nurcahya, A. (2017). Kualitas Tidur Pada Ibu Hamil Trimester III Sebelum dan Sesudah Dilakukan Senam Hamil di Puskesmas Kedungkandang Kota Malang. Politeknik Kesehatan Kemenkes Malang.

Pongsibidang, GS, dan M. A. (2019). Pengaruh Senam Prenatal Yoga terhadap Penurunan Kecemasan Ibu Hamil Trimester III. MKMI, 15(1), $55-62$.

Priharyanti, W, et al. (2018). Pengaruh Prenatal Yoga Terhadap Tingkat Kecemasan Pada Ibu Primigravida Trimester II dan III di Studio Qita
Yoga Kecamatan Semarang Selatan Indonesia. Ejournal Keperawatan, 9(1), 25-34. https://doi.org/11111

Rahmitha, N. (2017). Tingkat Kecemasan Pada Ibu Hamil Primigravida Trimester Ketiga Di Puskesmas Kecamatan Tamalanrea Makassar. Hasanudin.

Safriani, I. (2017). Pengaruh Senam Yoga Terhadap Kualitas Tidur Ibu Hamil Trimester III. Sekolah Tinggi Ilmu Kesehatan Insan Cendikia Medika.

Sindhu, P. (2011). Yoga Untuk Kehamilan. Qanita. 